\title{
Writing and publishing book
}

\author{
Sutanto Leo, Sekolah Tinggi Parwisata Bandung \\ Bandung Indonesia
}

\begin{abstract}
Writing and publishing book has become a strong intention of every educator. The published book is not only valuable for promotion and selfactualization but also for developing authority and public appreciation. The fact, many educators want to write books but they never start writing. Some have started writing books but they have never completed them. Only a few who have completed writing books have courage to send them to publishers. To start writing books, educators need to be engaged in real activities that involve them to decide on marketable book title, to arrange table of contents, to develop chapter by chapter, to write citations and references, to avoid plagiarism, and to complete the whole parts of the book. It is important that author knows the publisher such as the reputation, core products, and contract system of publishers which can indicate the credibility and trustworthiness of the cooperation with the author prior to sending his manuscript.
\end{abstract}

Keywords: writing, publishing, books, educators, manuscript, valuable, marketable

\section{Introduction}

Writing and publishing book has become a strong intention of every educator. The published book is not only valuable for promotion and selfactualization but also for developing authority and public appreciation [1]. The fact, many educators want to write books but they never start writing. Some have started writing books but they have never completed them. Only a few who have completed writing books have courage to send them to publishers [1]. Many educators said that they are not able to write and publish books although they have been succesful to write their thesis or dissertations. They do not know how to write books $(46.3 \%)$, do not have time $(35.7 \%)$, are not confident $(7.3 \%)$, do not have talent $(7.1 \%)$ and have no motivation (3.6\%) [2]. this paper is to convince that educators are very potential and able to write and publish books. A real educator is willing and able to write and publish his expertise. Books are eternal heritage [3].

\section{Writing books}

To start writing books, educators need to be engaged in real activities that involve them to decide on marketable book title, to arrange table of contents, to develop chapter by chapter, to write citations and references, to avoid plagiarism, and to complete the whole parts of the book.

Book title is expected to be interesting, short, active, powerful, reflecting the contents of the book, using the keywords, and marketable. The author is interested in the title that attracts readers' attention. It is normally short as it may less than eight key words. It is active as if it were like a child who never stops doing something such as yelling, shouting, running, kicking, jumping, throwing, etc. These all show that they have abundant ideas to be expressed through their restless activities. Powerful title is indicated by the words used in the title. Book title using modal auxiliaries such as can, could may, might, etc. suggest that the title is not powerful. The title reflects the whole contents of the book that show author's sharp and deep ideas.

A good content of a book follows the educational principles that include knowledge (learn to know), skills (learn to do) and attitude (learn to be and to live together) as suggested by UNESCO. In line with our ideology of Pancasila \& UUD 45, all books that contain knowledge, skills and attitude inspired by God are useful to teach, to show mistakes, to improve behavior and to educate people in the righteousness.

The contents of the book should be original, accurate and trustworthy and are free from plagiarism $[4,5]$. Original book content indicates the honesty of the author and uniqueness of the book as no authors have the same ideas. Accuracy of the content is very important. It is therefore, an author needs to 
verify every information and to check the accuracy of information. Trustworthiness is another important aspect of book content. It may also refer to the sources of information. This means that author is able to assess right sources prior to borrow the information for his book.

After the title is decided, it is time to do some brainstorming to pull and collect ideas until all ideas related to the title are gathered. Brainstorming stops whenever the ideas end. Then the ideas are shorted to pick up the most relevant and relevant ones. They are grouped and arranged in the order of sequence from broad to getting more specific information for books on general knowledge, from simple to more complicated information for books focusing on cognitive development, and following the sequence of process for books on services, production, etc. Ideas should be well organized, clear and interesting and are expected to be better than the available books in the market.

The organization of ideas are indicated by table of contents and the contents of each chapter. Good table of contents tells target readers that the book is more comprehensive, deeper and more complete than the other available books in the market as readers are very selective to decide and buy a book. They first try to check the table of contents to know whether the book is able to give information they require. This means that table of contents becomes the main consideration of book selection. That is why author needs to be very careful in organizing the table of contents including to compare with the similar books in the market.

Next the table of contents is developed into chapters of the book. Each chapter discusses in details based on the sub-headings of the chapter. The depth of each chapter is shown by the sub-headings of the chapter and the discussion of each sub-heading. Each chapter should consist of opening (starter) paragraph, development (main) paragraphs (main course), closing (dessert) paragraph and garnish. The opening paragraph contains the importance and the problems of the title as background information. For structured opening paragraph, it promises to the readers what sub-headings to be discussed within the chapter [3].

However, the length of the chapter does not always indicate the quality of the content.

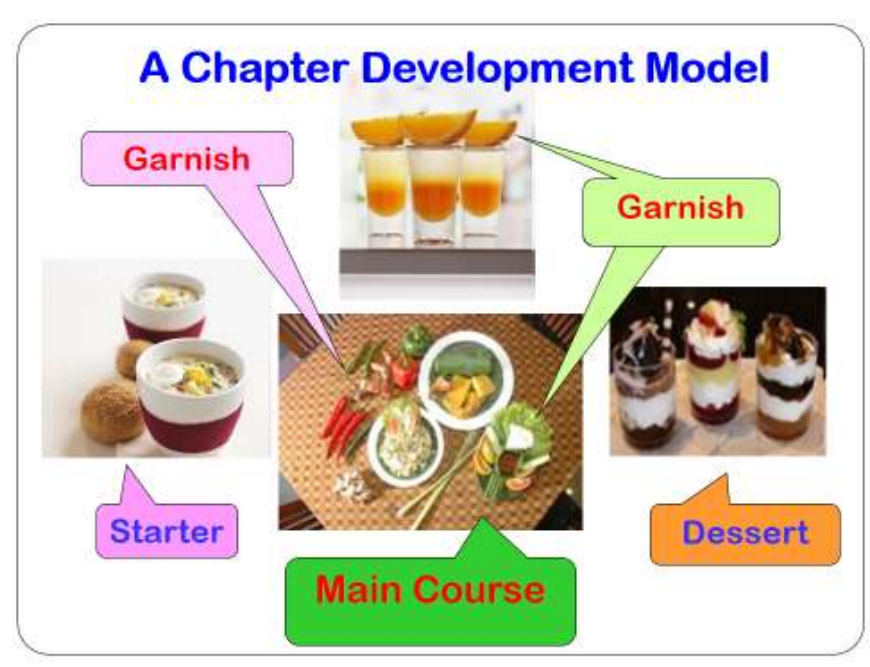

The paragraph development follows the logical flow and coherent logical to support the main idea of the paragraph [6]. The main idea is usually a phrase and appears in the main sentence, which generally is the first sentence in each paragraph. However, the authors who are experts include the main ideas are not always in the first sentence of the paragraph, but in the middle or end of a paragraph. Each paragraph contains: a) the main sentence (topic sentence) that contains the main idea; b) key explanatory sentence that supports the main sentence; c) an explanatory sentence next supports key explanatory sentence and subsequent explanatory sentence; d) a closing sentence special paragraph for a long paragraph when needed. Garnish is a decoration of the book chapter such photos, pictures, quotes, diagram, etc.

To support and complete author's ideas, it is a must to include citations. Synthesizing ideas, discussing the pros and cons from different sources strengthens and deepens the understandings of the authors and readers. Citations help authors be free from critiques and help readers find the right sources when further information is needed. However, books are different from other scientific reports such as thesis or dissertation that are common to include footnotes. Book publishers prefer to have text citations than footnotes as too many footnotes disturb readers.

In writing citations, it is important to follow a certain citation style appropriately. Otherwise, author's work or book may contain 
plagiarism. Plagiarism is an intentional or unintentional act to gain credit of a scientific report by citing a part or the whole parts of others without mentioning the source properly [7]. Plagiarism is a serious academic crime but the criminals never go to the jail. The degrees or positions they gained are withdrawn.

The language is clear, formal, smooth and if possible shining [1]. For novice writers, having clear and formal language is enough as smooth language may be produced by more experience writer. While shining language may be produced by very experience writers such as Shakespeare. Besides being formal, it should be free from language problems such as structure, diction, ambiguity and taboo words. Jargons are acceptable if there are no other suitable words or phrases in the target language. Spelling checks may help but writers still have to check the appropriateness of the language.

Editing and revising draft of the book. It is common that an author is also an editor. Selfediting is a very important process. An author should do everything he can do to revise the book draft. In this self-editing, the author is to fix three most important part of the manuscript both the contents that include organization, continuity, logical movement and the language such as redundant passages, ineffective transitions and sentence-structure issues [8].

\section{Publishing books}

Prior to send manuscript to publishers, it is important to know the reputation, core products, and contract system of publishers which can indicate the credibility and trustworthiness of the cooperation with the writers. Most publishers are profit oriented. They will always consider the marketing potential $(50 \%)$, value of knowledge, editorial (10\%) and writer's reputation (10\%) [1]. High reputation publishers have best quality product and wide or global marketing channel. They have clear vision and mission, business core product, publishing experience (not only printing), wide or global marketing network, willing to print more than three thousand (3000) books and honesty in paying royalty.

Good quality books are marketable and have high opportunities to be reprinted again and again. This kind of publishers usually apply what we call traditional contract. When the manuscript is approved to be published, all the publishing cost like editing, pictures or illustration drawing, setting, production, promotion, marketing will be provided by the publishers. The number of books sold will be reported every semester and the royalty which may range from $4 \%$ to $12 \%$ will also be paid per semester [1].

It takes time to publish books under traditional contract. The process starts from sending manuscript either in the form of a proposal or a complete manuscript. The proposal to be sent includes: the title of the book, table of contents, target users, rationale and scope, a sample of one or two chapters of the book, the expected length of the book and estimated date of completion and brief credentials of the author or curriculum vitae. A complete manuscript contains: a) Book cover, b) Opening parts of the book that include title of the book, acknowledgement, and table of contents. c) Main parts of the book that include chapter title, subtitles, definition, discussion, conclusion and or exercises, and d) closing parts of the book that consists of appendix, references, curriculum vitae and blurb.

A good publisher appreciates every proposal or manuscript received from authors. Publisher takes around three months to assess and decide whether the manuscript will be published or not. Ethically when the manuscript is under review, the author does not send the manuscript to the other publisher. When there is no response from the publisher until three months, the author has the right to ask the publisher. The answer from the publisher can be favorable (accepted) or unfavorable (rejected). There are some reasons why manuscript is rejected such as containing too many corrections, not better than what the books available in the market, not marketable or containing offences. However, the author has to respond adequately.

When the manuscript is approved to be published, a publishing contract agreement is prepared to be signed both the publisher and the author. It is important for the author to read the agreement carefully as there are a number of terms and conditions that bind the author and publisher. The agreement also states about the number of books published and percentage of the royalty the author gets and how the royalty is 
paid. A good publisher reports the total books sold every semester and transfers the royalty to the author.

Self-publishing is another way of publishing books. Here the author himself prepares the manuscript until ready to be printed. He edits both the contents and the language of the manuscript, sets the layout, designs the cover, and spends his money to publish the book. The whole cost of self-publishing is paid by the writers. The benefit or royalty can be at least $50 \%$. The amount of the benefit depends on the number of the books sold by the writers. The more books sold is the more money the writers obtain. Sometimes the writers are disappointed with their own editorial and the limited of the books sold.

\section{Conclusion}

Educators are very potential and able to write and publish their books. They need to be involved to decide on marketable book title, to arrange table of contents, to develop chapter by chapter, to write citations and references, to avoid plagiarism, and to complete the whole parts of the book. The manuscript is then sent to the right publisher that is suitable for their manuscripts. Whether the publisher accepts or rejects the manuscript, the author should be able to respond the letter from the publisher adequately.

\section{References}

[1] Leo, S. (2010) Kiat Jitu Menulis dan Menerbitkan Buku Jakarta: Erlangga

[2] Leo, S. et al (2007) English for Academic Purposes: Essay Writing, Andi: Jogyakarta

[3] Leo, S. (2013) Kiat Jitu Menulis Skripsi, Tesis dan Disertasi Jakarta: Erlangga

[4] Leo, S. (2013) Preventing Plagiarism around Our Campus in Indonesia, Journal of Tourism, Hospitality and Travel, Vol. 1. No.1, Dec 2013

[5] Leo, S. (2015) Membicu Buku SM, Majalah Suara Baptis, No. 3 November 2015

[6] Burton, S. and Steane, P. (2004). Surviving Your Thesis. London: Routledge

[7] Permendiknas (2010) Pencegahan dan penanggulangan plagiat di Perguruan Tinggi, Jakarta: Pendidikan Nasional

[8] Wise Ink (2012) AtFirst Draft: The 6 Steps to Revising Your Manuscript before Submission, from http://www.wiseinkblog.com/planning/at-first-draft-the-6-minimalsteps-to-revising-your-manuscript-before-submission/ 